\title{
A Bi-National Celebration of Contemporary Mexican Theatre November 12-15, 2008 - El Paso, Texas
}

\section{Timothy G. Compton}

Under the auspices of the University of Texas at El Paso (UTEP), approximately 100 scholars and creators of Mexican theatre gathered in a unique celebration which did indeed take place on both sides of the border, despite the difficulties of crossing that border and the ongoing drama of drug-related violence in Ciudad Juárez. Not a single participant, I am happy to report, was killed, shot at, kidnapped, or threatened in any way. The biggest problem was sleep deprivation (and it was common!), with readings of scholarly papers starting daily at 8:30 AM and continuing through early afternoons, staged readings in the later afternoons, then bus rides across the border to see evening plays in Cd. Juárez, and finally returning to El Paso as late as 12:30 AM. One day there was a much appreciated short break. The author, producer, director, and choreographer of the Celebration, Kirsten Nigro, brilliantly tapped into the fact that Mexico's XXIX Muestra nacional de teatro was scheduled to take place in Cd. Juárez in November. Come together it did, thanks to numerous UTEP sponsors, the Consulado General de México in El Paso (which hosted a reception for celebration participants at their facility), the Instituto Chihuahuense de la Cultura, and the Instituto Nacional de Bellas Artes. Thus, even sponsorship came from both sides of the border.

Approximately 60 ponencias were delivered in concurrent sessions. Editors of UTEP's Revista de literatura mexicana announced that an upcoming number of the journal would be dedicated entirely to expanded versions of the celebration's presentations. The Celebration also included three homenajes. The first honored Víctor Hugo Rascón Banda, and included presentations from Enrique Mijares, Rocío Galicia, Armando Partida, Jackie 
Bixler, Stuart Day and Kirsten Nigro. Galicia delivered a brilliant overview of the extensive corpus of theatre Rascón Banda penned, showing how it represented the complexity of Mexican society, and especially its ills. The other presentations focused less on the late great playwright's theatre; instead they ranged from a look at his public life (Partida) to very personal looks at his humanity as an individual, his relationship with family members, his hometown of Uruachic, his battle with cancer, and his relationship with the presenters themselves. The next homage was to Emilio Carballido and included four presentations, each focusing on different plays as keys to this late great playwright's theatre. Beatriz Rizk spoke on his short plays on Mexico City $(D F)$, which combine to create a sort of mural, Jackie Bixler put forth Fotografía en la playa as a very personal play based on Carballido's own family, Socorro Merlín analyzed the text of Zorros chinos and its premiere directed by Carlos Corona, and Héctor Herrera discussed Un gran ramo de rosas, which Carballido dictated to Herrera, and which premiered in Xalapa in August. The final homage included tributes from colleagues and family members honoring the life of Dr. María Isela Chiu Olivares, a native of the E1 Paso area, graduate of UTEP, professor at Utah State University, and scholar of Mexican literature.

A playwright roundtable generated considerable and sometimes heated discussion on the topics of funding for artistic work, how awards are granted (words such as "amiguismo," "nepotismo" and "canibalismo" surfaced), and the differences and tensions between Mexico City and the rest of the Republic, both in terms of funding and in the critical attention paid to theatre in those spheres. The roundtable included the following playwrights: Raquel Araujo from Mérida, Felipe Galván from Mexico City and Puebla,

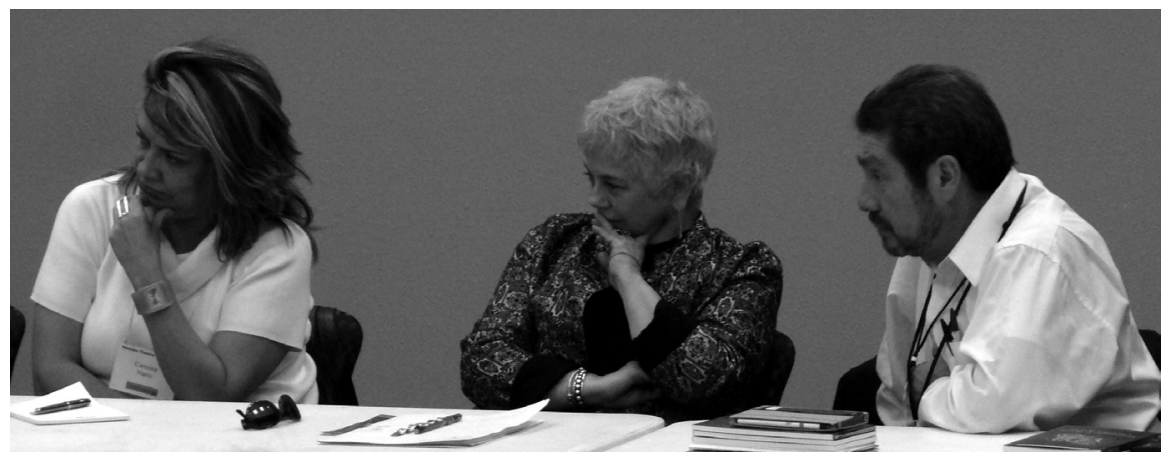

Mesa de dramaturgos: (L to R) Carmina Narro, Kirsten Nigro (moderator), Felipe Galván. Photo: Timothy G. Compton. 
Socorro Loeza from Yucatán, Manolo Medina from Monterrey, Carmina Narro from Mexico City, Ricardo Pérez Quitt from Atlixco, Hugo Salcedo from Tijuana, and Manuel Talavera from Chihuahua.

A session on recent publications in Mexican theatre included presentations from Gastón Alzate and Paola Marín on the online magazine Karpa, Rocío Galicia on the numerous books published in 2008 through Enrique Mijares, Ricardo Pérez Quitt on his magazine containing playtexts, Felipe Galván on the $3^{\text {rd }}$ edition of Teatro del ' 68 as well as new companion volume, Manuel Talavera on several recent theatre books from Chihuahua, and Rodolfo Obregón on the numerous publications available from the Centro de Investigación Teatral Rodolfo Usigli (CITRU). This session was a very encouraging testimonial to the fact that Mexican theatre is growing considerably.

As mentioned above, several dramatic readings occurred on the UTEP campus. These included a monologue version of Elena Garro's Los perros performed by Esmeralda Ceballos (see Latin American Theatre Review (LATR) 42.1 (Fall 2008): 115-16, for comments on a fully staged version of this play), Nocturnos by Edna Ochoa, a play in which a couple tries to overcome resentments and disappointments in their dark marriage, Quimicos para el amor by Carmina Narro (see LATR 37.1 (Fall 2003): 156-57), and Papá está en Atlántida by Javier Malpica. For this critic, the reading of Malpica's play was one of the most memorable and moving theatre performances of the entire Celebration. Malpica's play consists of a series of conversations between young brothers whose mother has died and whose father leaves Mexico for Atlanta (hence the name of the play) and later on they follow. Debbie Savietz directed a pair of (non-theatre) UTEP students in the roles. Oscar García played the older brother, whose age I imagined at 10-11 years old. He acted as the guide to his little brother (age 7-8?), played by Raúl Anton Muñoz, in the rough game of life, helping him negotiate extended family as they went to live with their grandmother, a new school, their grandmother's death, the prospect of crossing the border to join their father, and finally the actual journey. García and Muñoz were obviously not the age of the characters, but they captured vividly their tender and often humorous relationship. Muñoz played the little brother brilliantly, effectively projecting all sorts of juvenile doubts and fears and excitement and questions. His was a nervous but wideeyed energy of a young boy in the midst of big life changes. With clenched fists covering his eyes he characterized real young boy fear when his brother mischievously threatened him with the arrival of the devil if he turned out the 


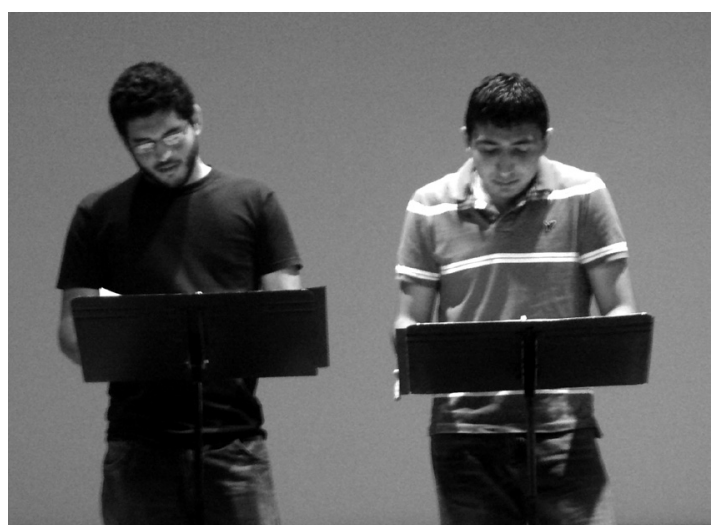

Papá está en la Atlántida. Photo: Timothy G. Compton.

light at the end of the day. His antics as he dreamed of playing baseball for the Braves in Atlanta were rich. His anguish at needing to use the bathroom during their long trip seemed real. And through it all García played beautifully the less flamboyant role of the steady older brother who enjoyed both observing his little brother as well as having power over him. Although there were no props and the pair remained standing the entire play until the end, between scenes they would pick up their stands with the texts and put them down in a slightly different spot, clearly indicating a change in time and space. At the end of the play, when the pair crossed the border into the American dessert, grew exhausted, and eventually sat down and then fell asleep, they clearly left themselves mortally vulnerable in numerous ways. Many audience members wept. This performance was an excellent reminder that famous actors, magnificent sets, and elaborate costumes are very nice, but the magic of outstanding theatre can happen with an excellent text, good actors, good direction, a space, and a receptive audience.

Celebration participants were able to take in four plays of the Muestra in Cd. Juárez, although the final night they had to choose between Bárbara Colio's Pequeñas certezas directed by Claudia Ríos (see LATR 42.1 (Fall 2008): 113-14, for my comments on this play as performed by the same cast in Mexico City) or a bundle of four short plays by Emilio Carballido under the umbrella title of $D F$ Teatro. The Muestra actually began on Friday, November 7 and ran for nine consecutive days in Cd. Juárez. It included performances of twenty plays, four roundtable discussions, a presentation of books from Chihuahua, and a presentation of a trio of awards: the Medalla de Oro de Bellas Artes went to Luis Martín Garza Gutiérrez for his theatre work at the Universidad de Nuevo León, the Medalla Xavier Villaurrutia to Fernando Moguel for his 30 years of theatre photography, and the Premio de Periodismo Cultural del Noreste to Carmen Becerra. The twenty plays were performed by groups from ten states: Baja California, Chihuahua, Distrito 
Federal, Hidalgo, Jalisco, Michoacán, San Luis Potosí, Tamaulipas, Veracruz, and Yucatán. (See http://www.muestranacionaldeteatro.blogspot.com/ for a listing of all the plays performed at the Muestra).

For this critic's palate, Ma 'tinaa 'ti Kech (No te entiendo) was the most delicious play the Celebration's participants witnessed. Written by Socorro Loeza and Juan de la Rosa and directed by de la Rosa, it was performed by the group Maak Mayaab (Gente que no abunda en el mundo). As its title suggests, this play came from the state of Yucatán, and much of the dialogue actually did take place in Mayan. It captured perfectly the tensions between tradition and change, small towns and cities, Mayan and Spanish. Four characters made up the cast, each representing a different generation of a family, starting with a baby "played" by a doll, the mother played by Mary Llama, the grandmother played by Socorro Loeza, and the great-grandfather played by Espiridión Acosta. The grandmother stood between diametrically opposed generations - her father spoke only Maya, wore traditional Mayan clothing, and had lived far from cities his entire life; her daughter spoke only Spanish, wore western clothing, and had moved to the big city of Mérida. The title reflects the

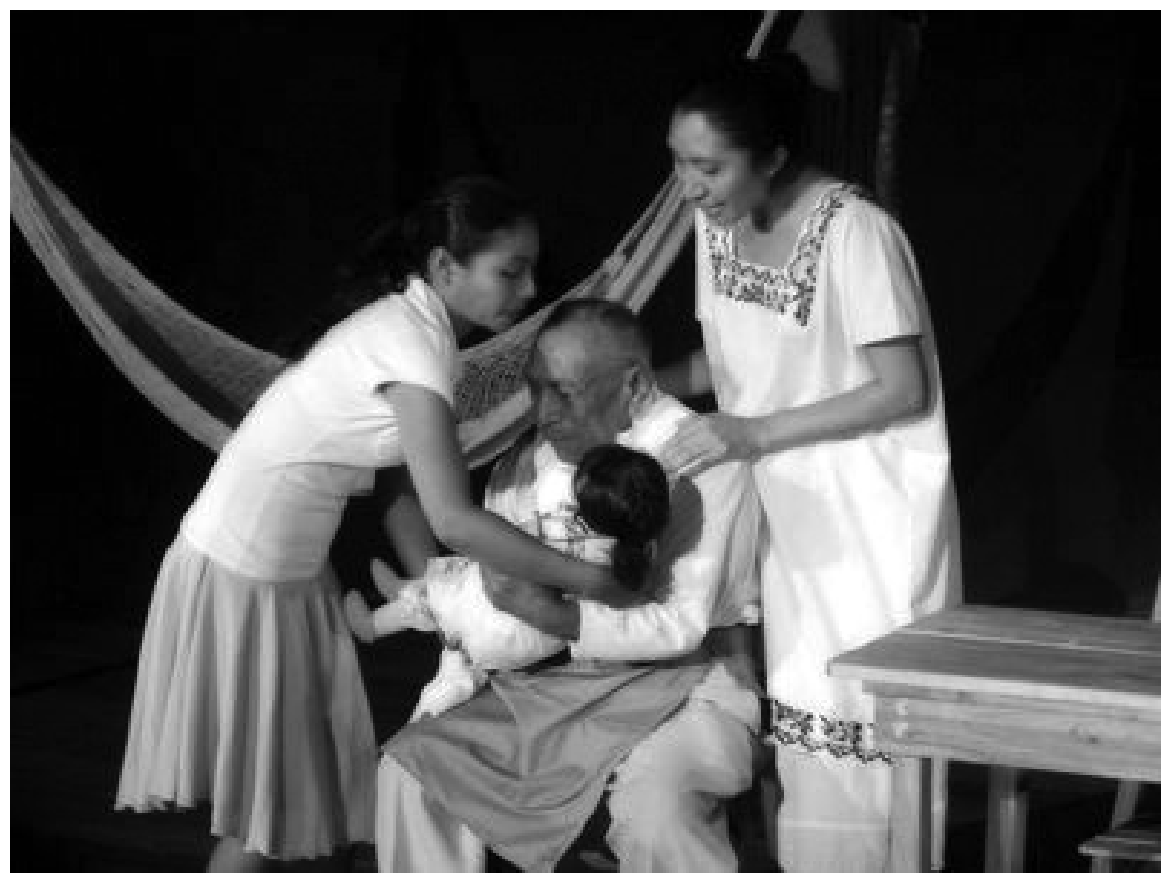

Ma'tinaa 'ti Kech (No te entiendo). Photo: José Jorge Carreón. 
feelings of both grandfather and his granddaughter, but the dramatic tension surfaced in the granddaughter, who as a young, single mother, had suffered humiliation and discrimination in Mérida because of her Mayan heritage, and was needing to make decisions about her daughter - whether to have her learn Mayan, wear traditional Mayan clothing, participate in Mayan ceremonies, or distance her from family to a westernized existence. Her dilemma never did reach a resolution, but rather climaxed in a final monologue during which she tearfully voiced her agony to the audience over the difficulties of her position and the fact that she did not know what was best for her baby, whether to embrace tradition or reject it. The interactions in Mayan between the two members of the older generations were rich, exposing the audience to a lovely but, for most, unfamiliar language, and it was particularly sweet when the two interacted vivaciously with the baby. The set was sparse, but effectively showed the basics of a humble casita yucateca, complete with a hammock as the baby's crib. The acting was as unpretentious and effective as the play itself, beautiful and convincing. If ever anyone should continue to foolishly argue that the only good theatre in Mexico happens in its capital city, this outstanding play would disprove that fallacy once and for all.

The Telón de Arena group from Cd. Juárez delivered an admirable performance of Rojo amanecer, written by Xavier Roble and directed by Perla de la Rosa. A classic Tlatelolco 1968 piece, it focused on a family which lived in an apartment overlooking the plaza and on the tragic events of October 3, 1968, which ended with the violent deaths of family members and their friends at the hands of the Mexican army. Several theatrical details added to the impact of the powerful script. First of all, photographic images of the Plaza de Tlatelolco on October 3, 1968, were projected onto the set between scenes. Second, newspapers about the original event had been blown up and papered the walls of the apartment represented. Third, sounds of the 1960s were used, including protest music and actual snippets of student rallies in the 1968 movement. A set detail added to the play's allure: between the first and second acts the perspective turned 180 degrees, so what had been at the back of the stage in act one was at the front in act two. All those details simply added to a powerful play which represented well the tragedy, the brutality, the abuse of power, and the hypocrisy all associated with one of Mexico's most infamous historical moments. The program suggested a parallel to the current violence in $\mathrm{Cd}$. Juárez. The circumstances were certainly different, but the effect of senseless violence on the citizenry may be sadly similar. 


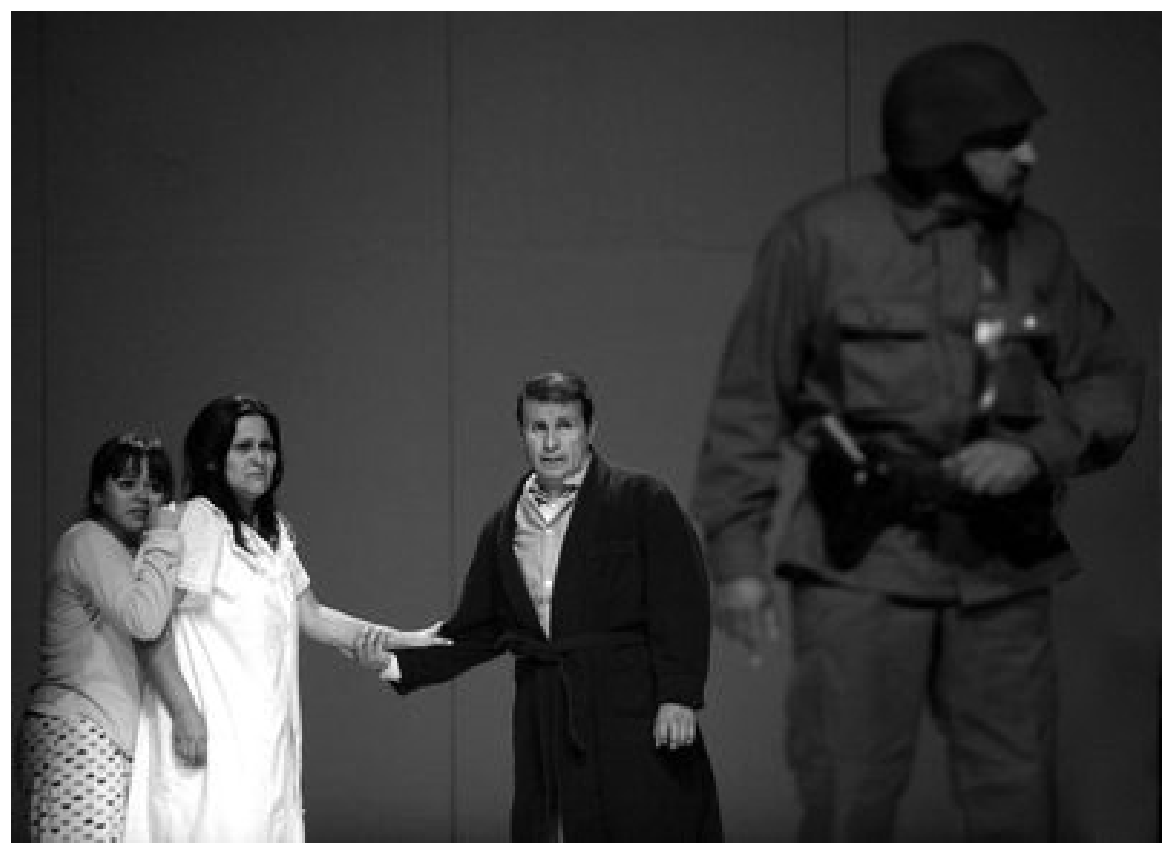

Rojo Amanecer. Photo: Fernando Moguel.

DF Teatro, as was mentioned above, consisted of four short plays by Emilio Carballido. The program credited Alberto Lomnitz and Ricardo Ramírez Carnero with the "Dirección general" and Mario Marín del Río with the set design. The set changed cleverly and dramatically from play to play. In $\mathrm{El}$ censo it portrayed the interior of a clothing sweatshop, in Ni cerca, $n i$ distante a tiny room in a hotel, in Delicioso Domingo an expansive street scene along Avenida Reforma, and in Conmemorantes a surreal, dark, tomb-like space. The first, directed by Bruno Ruiz, was performed as a highly stylized farce, delicious in its exaggerations and overblown rhetoric, and acting by a brilliant cast. The second, directed by Alaciel Molas, portrayed a troubled couple crushed by poverty and lack of opportunity who decided to take their own lives in a twisted attempt at glory. "Doubles" of the couple, in pajamas, danced around and gave advice to the two, which was intriguing, but never really came fully together. Perhaps that sense of disquieting lack of cohesion created a desired effect. The third play, directed by Luis Rodríguez, showed a lighter side of life, portraying a pair of men and the women they had hired (wink wink) in the wee hours of the morning as joggers and roller skaters started into their daily routines. The final play, directed by Abel Ignacio 


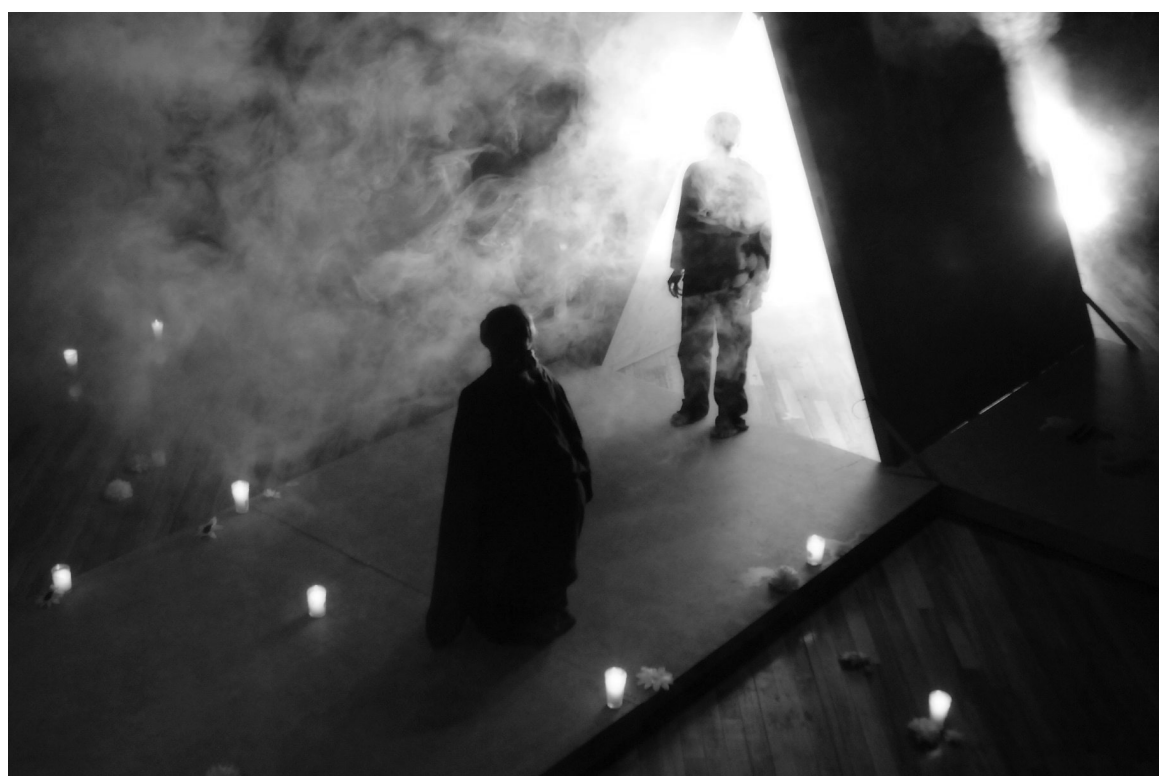

Conmemorantes. Photo: José Jorge Carreón.

Hernández, was also a 1968 play, focusing on the disappeared and those that miss them. It featured a very dark set lit by candles, dark clothing, white masks, and a lot of smoke. Voices from beyond the grave combined with the living, as well as wistful percussion and flute to further the otherworldly effect. In this combination of short plays, spectators glimpsed strikingly different sides and tones of Mexico City, as well the amazing range of Carballido's theatre.

I regret to report that the other Muestra play which Celebration participants saw was not on an artistic par with the other plays I have mentioned here. Berman's classic Entre Villa y una mujer desnuda had much of the text cut, was lacking in several of the acting roles, and simply lacked zip, other than the occasional histrionic interventions of the ghost of Pancho Villa.

And so we see that this Celebration fell short of perfection. Nonetheless, for specialists in contemporary Mexican theatre, it came close.

Northern Michigan University 